\section{S INGULAREUROPE}

The Economy and Polity of the European Community after 1992 William James Adams, Editor

Leading international experts in the fields of economics, political science, business, and law examine the implications of the fully integrated European market.

Contributors are William James Adams, Severin Borenstein, Bo Carlsson, Gunter Dufey, Reinhard Ellger, John Jackson, Alexis Jacquemin, Frederic Jenny, Stephan Leibfried, Ernst-J. Mestmacher, Tommaso PadoaSchioppa, Gary Saxonhouse, Joan Steinbruner, William Wallace, Joseph Weiler, and Susan Woodward. cloth $\$ 45.00$

\section{THENEW EUROPE}

\section{Changing Economic Relations between East and West}

\section{Susan Senior Nello}

An analysis of the problem of integrating Eastern Europe into the economy of Europe as a whole.

cloth $\$ 54.50$

\section{THEEUROPEAN CHALLENGE}

\section{Industry's Response to the 1992 Programme}

\section{David G. Mayes, Editor}

A study of the structure of eleven separate European industries and an assessment of the Single Market measures that affect them as well as each industry's strategic responses to Program 1992 initiatives. cloth $\$ 59.50$

Credit card orders Fax to $(800)$ 876-1922

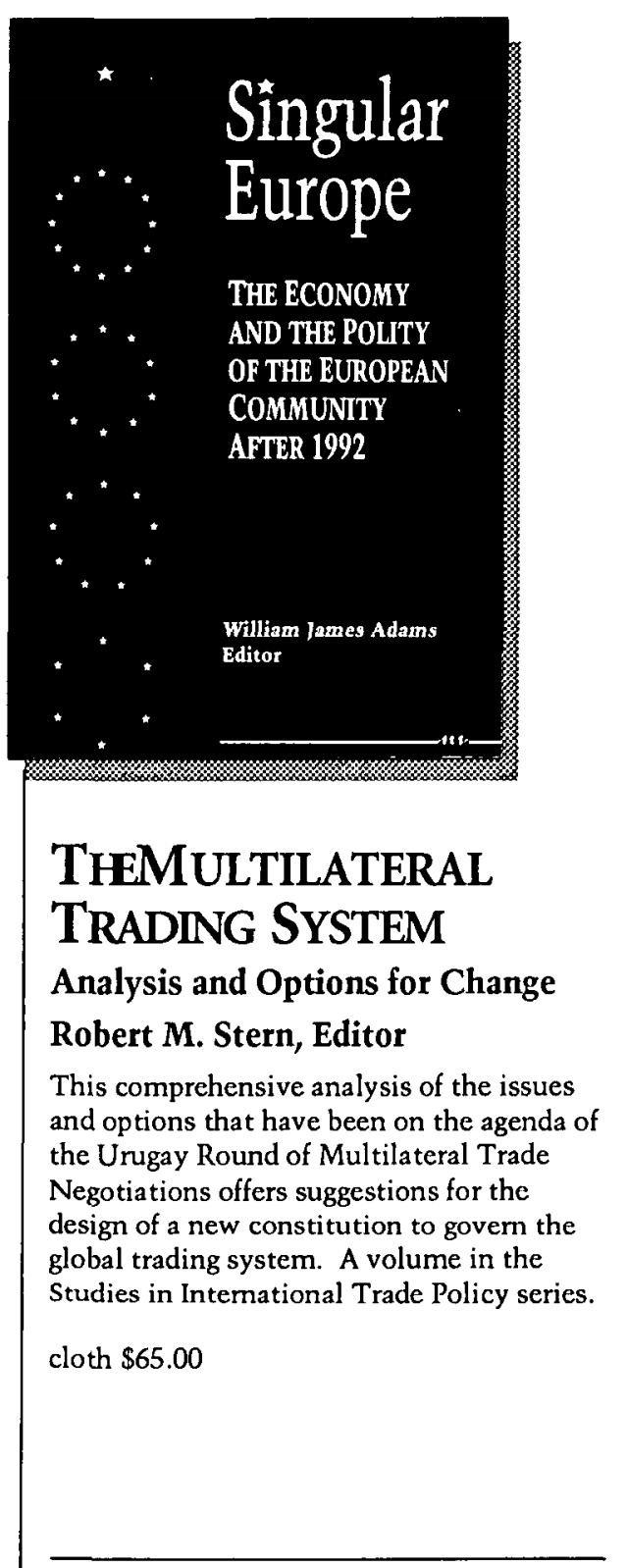

The University of Michigan Press Dept. AS

Ann Arbor, Michigan 48106-1104 


\section{International $\mathbf{O}_{\text {rganization }}$ Back Issues}

Vol. 33, No. 1, Winter 1979 The Political Consequences of the Product Cycle: Industrial History and Political Outcomes James R. Kurth

Vol. 33, No. 3, Summer 1979 The Management of Surplus Capacity: Or How Does Theory Stand UP to Protectionism 1970s Style? Susan Strange

Vol. 33, No. 4, Autumn 1979 An Economic Theory of Mutually Advantageous /ssue Linkages in International Negotiations Robert D. Tollison, Thomas D. Willett

Vol. 34, No. 1, Winter 1980 Towards a Marxist Theory of European Integration Peter Cocks

Vol. 34, No. 2, Spring 1980 Self-Reliance in Theory and Practice in Tanzanian Trade Relations Thomas J.

Biersteker

Vol. 35, No. 2, Spring 1981 Sphere of Flying: The Politics of International Aviation Christer Jönsson

Vol. 35, No. 3, Summer 1981 Third World Indebted Industrialization: International Finance and State Capitalism in Mexico, Brazil, Algeria, and South Korea

Jeff Frieden

Vol. 35, No. 4, Autumn 1981 The GATT and the Regulation of Trade Barriers: Regime Dynamics and Functions Jock A. Finlayson, Mark W, Zacher

Vol. 36, No. 1, Winter 1982

The Political Economy of

Indian Joint Industrial

Ventures Abroad Dennis J.

Encamation

Vol. 36, No. 3, Summer 1982

Managing the Global

Commons Per Magnus

Wijkman

\section{Featured Articles}

Vol. 36, No. 4, Autumn 1982 Capitalism and Hegemony: Yorubaland and the International Economy David D. Laitin

Vol. 37, No. 1, Winter 1983 Hegemonic Stability Theory and Nineteenth-Century Tariff Levels in Europe Timothy J. Mckeown

Vol. 37, No. 4, Autumn 1983 The Unraveling of the MultiFiber Arrangement, 1981: An Examination of International Regime Change Vinod K. Aggarwal

Vol. 38, No. 1, Winter 1984 Breaking with Orthodoxy: The Politics of Economic Policy Responses to the Depression of the 1930s Peter Alexis Gourevitch

Vol. 38, No. 2, Spring 1984 The Hegemon's Dilemma: Great Britain, the United States, and the International Economic Order Arthur A. Stcin

Vol. 38, No. 3, Summer 1984 Policy Coordination by Major Western Powers in Bargaining with the Third World: Debt Relief and the Common Fund Barbara B. Crane

Vol. 38, No. 4, Autumn 1984

Economic Structure and International Security: The Limits of the Liberal Case Barry Buzan

Vol. 39, No. 1, Winter 1985 The Empire Strikes Back: The Transformation of the Eastern Bloc from a Soviet Asset to a Soviet Liability Valerie Bunce

Vol. 39, No. 4, Autumn 1985 The Limits of Hegemonic Stability Theory Duncan Snidal
Vol. 40, No. 1, Winter 1986

Neomercantilism and International Economic Stability Paolo Guerrieri, Pier Carlo Padoan

Vol. 40, No. 3, Summer 1986 International Human Rights:

A Regime Analysis Jack

Donneily

What Is Nationalism and Why Should We Study II?

Emst B. Haas

Vol. 41, No. 1, Winter 1987 Crisis Prevention and the Austrian State Treaty

Deborah Welch Larson

Vol. 41, No. 3, Summer 1987 Nordic Economic Policies in the 1970s and 1980s Lars Mjøset

Vol. 41, No. 4, Autumn 1987 Quari-States, Dual Regimes, and Neoclassical Theory: International Jurisprudence and theThird World Robert H. Jackson

Vol. 42, No. 2, Spring 1988 NATO and the Persian Gulf: Examining Intra-alliance Behavior Charles A. Kupchan

Vol. 43, No. 1, Winter 1989 The Impact of Ideas on Trade Policy: The Origins of U.S. Agricultural and Manufactur. ing Policies Judith Goldstein

Vol. 44, No. 3, Summer 1990 Socialization and Hegemonic Power G. John Ikenberry, Charles A. Kupchan Multilateral Negotiations: $A$ Spatial Analysis of the Arab. Israeli Dispute Bruce Bueno de Mesquita 
Vol. 44, No. 4, Autumn 1990

Exploring the "Myth" of

Hegemonic Stability

Isabelle Grunberg

How Japan Affects the

International System Henrik

Schmiegelow and Michèle

Schmiegelow

Vol. 45, No. 2, Spring 1991

The East European Countries and GATT: The Role of

Realism. Mercantilism, and

Regime Theory in Explaining

East-West Trade Negotiations

Leah Haus

Can Orthodox Stabilization

and Adjustment Work?

Lessons from New Zealand, 1984.90 Herman Schwartz
Vol. 45, No. 3, Summer 1991 Political Leadership and Regime Formation: On the Development of Institutions in International Sociey Oran R. Young German Trade Policy in Eastern Europe, 1890-1990: Preconditions for Applying International Trade Leverage Roben Madk Spaulding, Jr.

Vol. 46, No. 1, Winter 1992 SPECIAL ISSUE: Knowledge, Power, and Internationl Policy Coordination Edited by Peter M. Hass, with Emanuel Adler, William J. Drake, Kalypso Nicolaïdis, Raymond F. Hopkins, G. John Ikenberry, Ethan Bamaby Kapstein, M. J. Peterson, James K. Sebenius
Vol. 46, No. 2, Spring 1992 A Tale of Two Worlds: Core and Periphery in the Past-Cold War Era James M. Goldgeier and Michael McFaul International Cooperation and Institutional Choice: The European Community's Internal Market Geoffrey Garrell

Vol. 46, No. 3, Summer 1992 Symposium: Multilateralism with John Gerard Ruggie, James A. Caporaso, Steve Weber, Miles Kahler

\section{International $\mathbf{O}_{\text {rganization }}$}

Please send me the following back Issue(s):

$\begin{array}{lll}-33.1 & -37.1 & -41.3 \\ -33.3 & -37.4 & -41.4 \\ -33.4 & -38.1 & -42.2 \\ -34.1 & -38.2 & -43.1 \\ -34.2 & -38.3 & -44.3 \\ -35.2 & -38.4 & -44.4 \\ -35.3 & -39.1 & -45.2 \\ -35.4 & -39.4 & -45.3 \\ -36.1 & -40.1 & -45.1 \\ -36.3 & -40.3 & -45.2 \\ -36.4 & -41.1 & -45.3\end{array}$

I am ordering at: copy (coples)

Prepayment is required. Send check or money order - drawn on a U.S. bank In U.S. funds, payable to International Organization-MasterCard or VISA number to:

Institution rate: $\$ 22.00$ per Issue

Indlvidual rate: $\$ 11.00$ per Issue

Add $\$ 5$ per issue for shipplng outside U.S.A. Canadians add additional $7 \%$ GST. TOTAL
Circulation Department MTT PRESS JOURNALS SS HA YWARD STREET CAMBRIDGE, MA 02142.1399 USA

TEL: (617) 253-2889 FAX: (617) 258-6779 hiscox@mitvma.mil.edu

Check or money order - drawn on $₫$ U.S. benk in U.S. funds, payable to Internation al Organization-is enclosed.

Charge to my _ MasterCard _ VISA Account No.

Expiration Date SIgnature/Today's Date

Print cardholder' I name

Send to (plesse print clearly):

Name

Company/Department

Address

City/State/Province/Tlp/Country

Daytime phone Grn from 


\section{JOURNAL OF POLITICS}

Editors: Cecil Eubanks, Louisiana State University Ronald Weber, University of Wisconsin-Milwaukee

The University of Texas publishes the Journal of Politics for the Southern Political Science Association. As the oldest regional political science journal, the JOP offers a blend of various styles of political science and maintains its representation of the broad scope of the discipline.

\section{Articles for 1992 include:}

Lawrence Baum Membership Change and Collective Voting Change in the United State Supreme Court

Patrick James and The Most Dangerous Game: Superpower

Frank Harvey Rivalry in International Crises, 1948-1985

James L. Gibson, Raymond Democratic Values and the Transformation

M. Duch, Kent L. Tedin of the Soviet Union

Steven Forde Varieties of Realism: Thucydides and Machiavelli

Bradley C. Canon The Supreme Court as a Cheerleader in Politico-Moral Disputes

Barbara Sinclair The Emergence of Strong Leadership in the 1980s House of Representatives

Individual single copy rate/ $\$ 8$; Institution single copy rate/\$11 Foreign add $\$ 2.50$ for postage.

Subscription rates (one year): Individual $/ \$ 20 ;$ Institution $/ \$ 40$ Foreign add $\$ 8.25 /$ subscription for postage.

\section{University of Texas Press, Journals, Box 7819, Austin, Texas 78713}

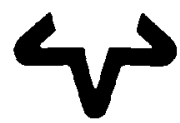




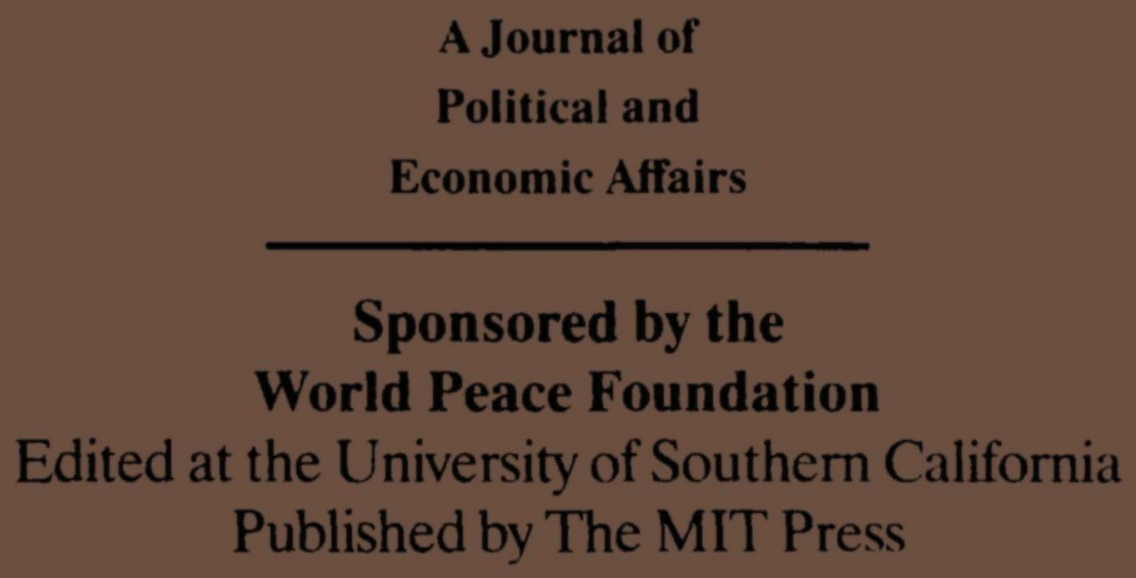

